\title{
A new member of the family Plotopteridae (Aves) from the late Oligocene of British Columbia, Canada
}

\author{
Gary Kaiser, Junya Watanabe, and Marji Johns
}

\begin{abstract}
The discovery of an avian fossil, in the upper Oligocene Sooke Formation rocks on southwestern Vancouver Island, British Columbia, is the first example from Canada of the Plotopteridae, an extinct family that lived in the North Pacific from the late Eocene to the early Miocene. The fossil is a nearly complete, well-preserved coracoid that exhibits the diagnostic features of the family. Stemec suntokum is described as a new genus and species for this family of extinct, wing-propelled diving birds. Coracoids are exceptionally informative bones that lie at the focus of forces acting on the shoulder where they play a major role in avian locomotory biomechanics. The coracoid of Stemec has an unusually narrow, conical shaft that differs fundamentally from the broad, flattened coracoids of other avian groups.
\end{abstract}

Gary Kaiser. Royal BC Museum, 675 Belleville Street, Victoria British Columbia, Canada V8W 9W2. gwkaiser44@gmail.com Junya Watanabe. Department of Geology and Mineralogy, Kyoto University, Sakyoku Kitashirakawa Oiwakecho, Kyoto, 606-8502 Japan. watanabe-j@kueps.kyoto-u.ac.jp Marji Johns. Royal BC Museum, 675 Belleville Street, Victoria British Columbia, Canada V8W 9W2. mjohns@royalbcmuseum.bc.ca

Keywords: Avian fossil; British Columbia; New species; North Pacific; Oligocene; Plotopteridae

Submission: 29 April 2015 Accepted: 1 November 2015

\section{INTRODUCTION}

Paleogene sedimentary deposits of the Carmanah Group on southwestern Vancouver Island are well known for their rich diversity of fossil mollusks (Clark and Arnold, 1923). They commonly form shell coquinas that occasionally include the bones of marine mammals, such as the desmostylid Cornwallius sookensis (Cornwall, 1922) and the cetacean Chonecetus sookensis Russell, 1968, but bird fossils are rare. In 1894, a fragmentary tarsometatarsus of the pelagornithid Cyphornis magnus Cope, 1894 was found in Carmanah Group rocks (Wetmore, 1928) and is now in the National Museum of Canada (P-189401/6323). No additional avian fossils were reported for 120 years until late 2013 when portions of two avian tibiotarsi were found near Sooke at the southwest end of Vancouver Island and given to the Royal BC Museum (RBCM.EH2013.033.0001.001 and RBCM.EH2013.035.0001.001). Although both of those specimens are similar in size and shape to bones from extant cormorants (Phalacrocoraci-

http://zoobank.org/20FDDF8C-7CAC-4345-9574-7395064AED79

Kaiser, Gary, Watanabe, Junya, and Johns, Marji. 2015. A new member of the family Plotopteridae (Aves) from the late Oligocene of British Columbia, Canada. Palaeontologia Electronica 18.3.52A: 1-18

palaeo-electronica.org/content/2015/1359-plotopterid-in-canada 


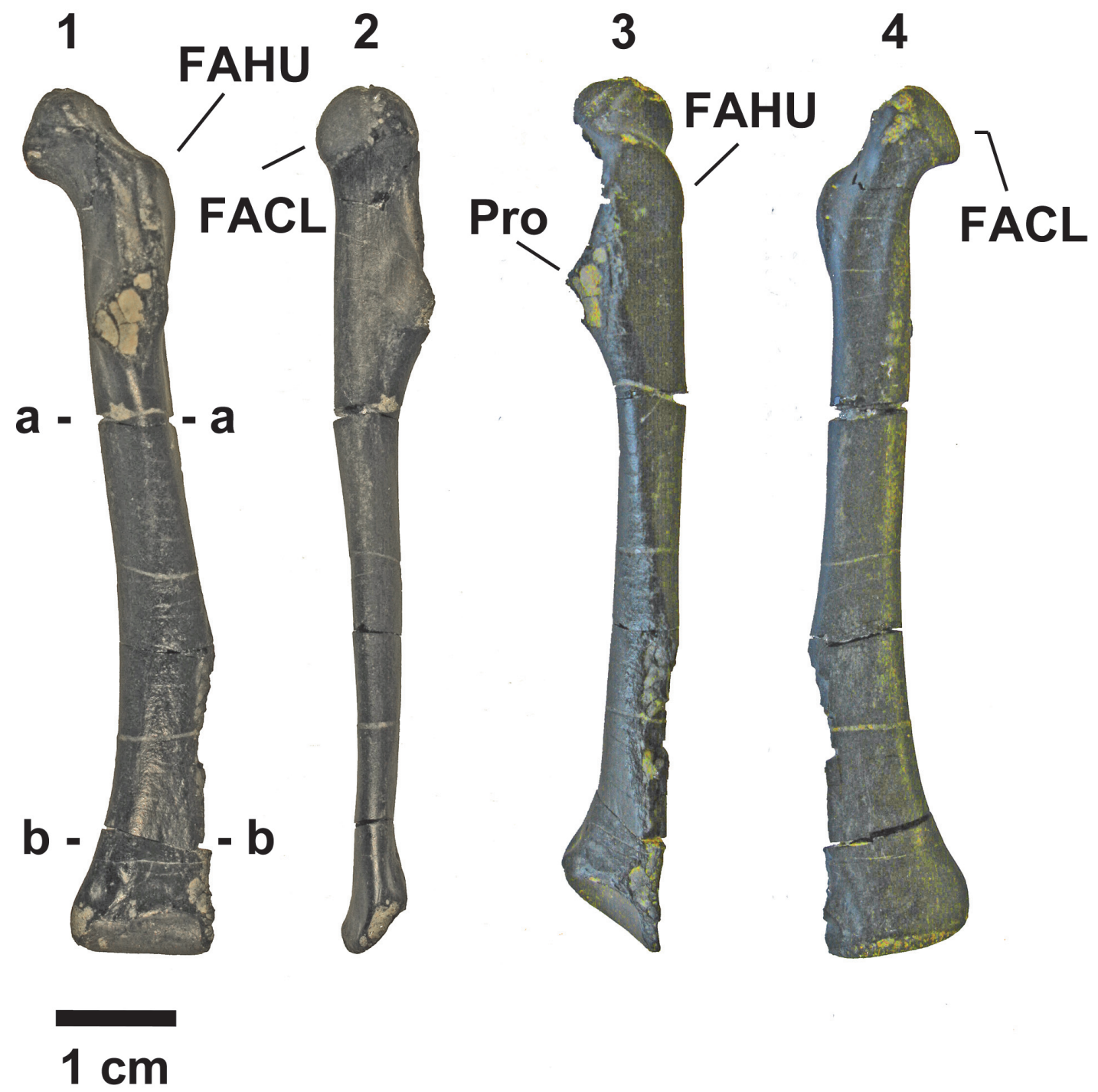

FIGURE 1. Stemec suntokum gen. et sp. nov. holotype right coracoid (RBCM.EH2014.032.0001.001) from the Sooke Formation, at the southwestern end of Vancouver Island, British Columbia as re-assembled after preparation. 1-4, dorsal (1), medial (2), lateral (3), ventral (4) aspects. Abbreviations: FACL, facies articularis clavicularis; FAHU, facies articularis humeralis; PRO, procoracoid.

dae), they are incomplete and confident identification is problematic. Late in 2013 , a third avian fossil, a well-preserved coracoid, was found at the same site (RBCM.EH2014.032.0001.001) (Figures 1-3).

The elongate shaft and structural features of the new fossil suggest that it is a small member of the Plotopteridae and not a cormorant. Plotopterids are an extinct family of flightless, wing-propelled diving birds that are thought to be the sister group to the cormorant-darter clade (Smith, 2010). The location of its discovery supports this assessment. Fossil plotopterids are well known from Japan and the west coast of the United States, but fossils of near contemporaries among the cormorants are known only from Australia (Worthy, 2011) and Europe (Mayr, 2010, 2015) (Table 1).

The first fossil described for the Plotopteridae consists of a portion of the omal end of a coracoid from the Oligocene Pyramid Hill Sand Member (Jewett Sand Formation) of California (LACM 8927), (Figure 3.1). Hildegarde Howard (1969) 

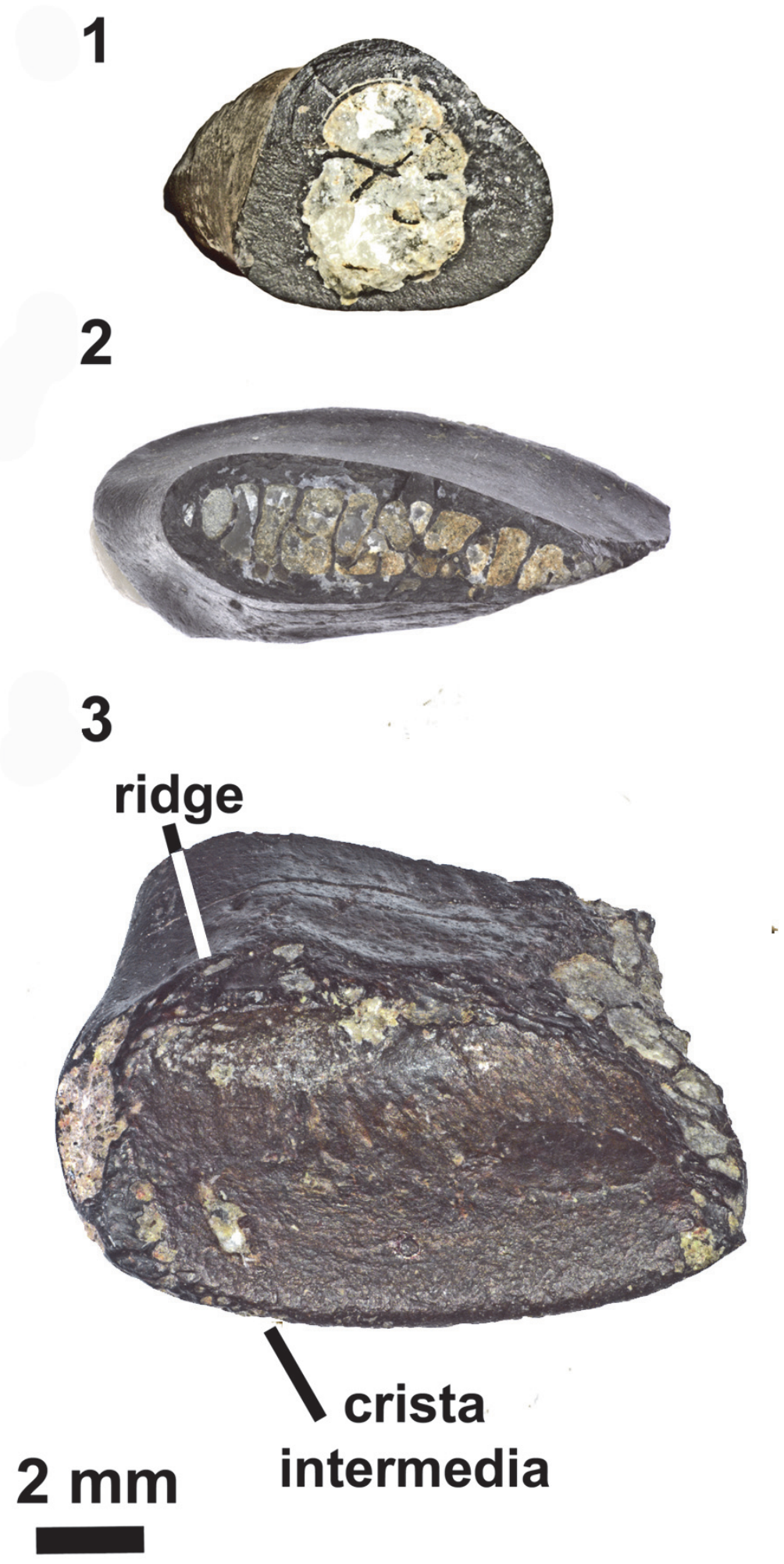

FIGURE 2. Components of Stemec coracoid (RBCM.EH2014.032.0001.001). 1, cross-section of the shaft immediately caudal of the cranial portion (a-a of Figure 1.1); 2, cross-section cranial to the sternal segment (b-b of Figure 1.1 ); and 3 , structural features near the sternal articulation. 

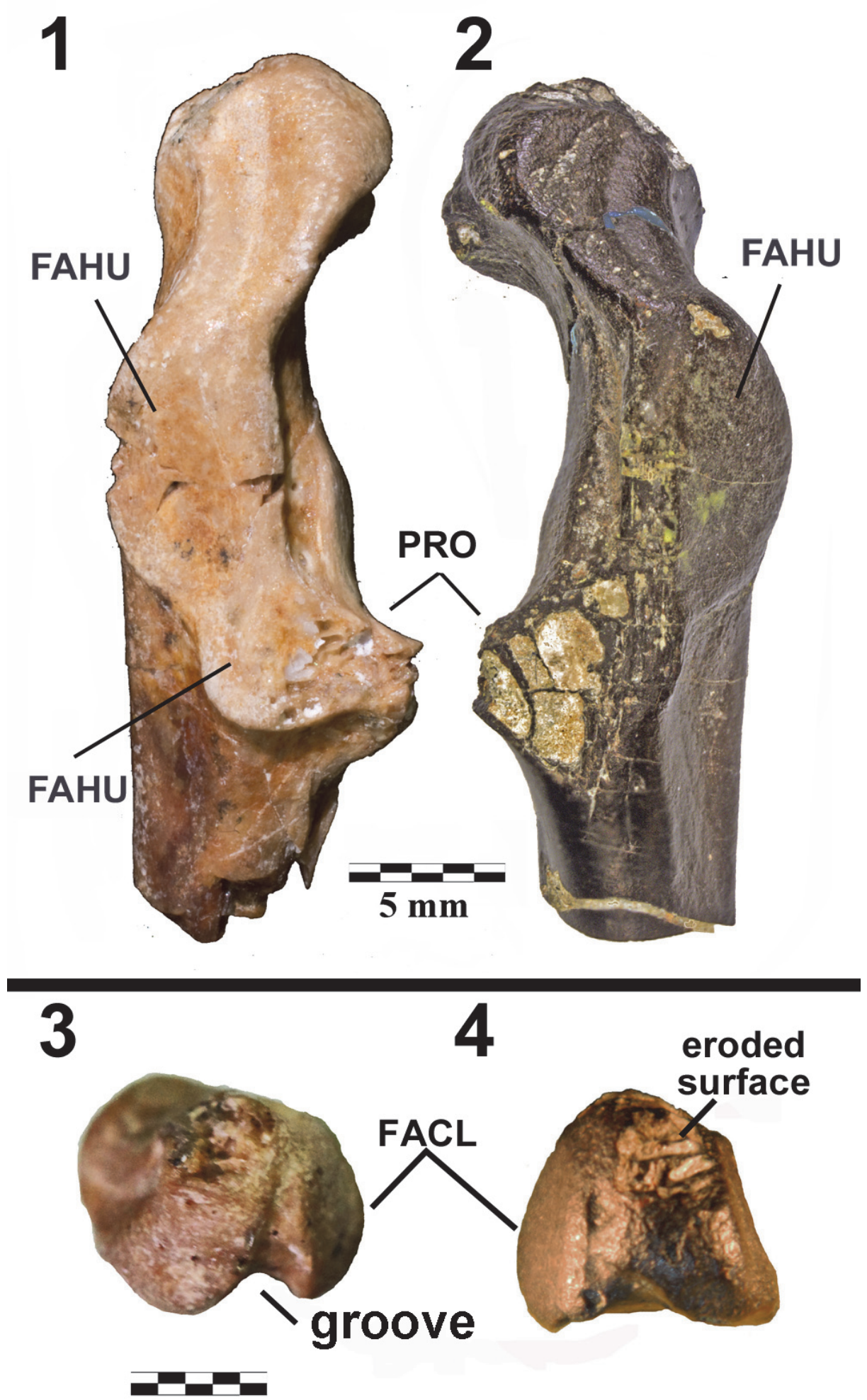

\section{$5 \mathrm{~mm}$}

FIGURE 3. Comparison of the acrocoracoid of Plotopterum joaquinensis (LACM 8927) (1 and 3) to Stemec suntokum (RBCM.EH2014.032.0001.001) (2 and 4). 1 and 2, dorsal aspects, 3 and 4, cranial aspects. See Figure 1 for abbreviations. 
described it as Plotopterum joaquinensis. The fragment of bone has "The swelling of the lower triosseal region [that] tends to narrow and deepen the passageway for the pectoral tendon ..." (Howard, 1969, p. 69). That swelling is a discrete character of wing-propelled diving birds and appears in penguins and auks. Its presence in LACM 8927 prompted Howard to erect a new family within the traditional Pelecaniformes.

In recent phylogenetic analyses of the "waterbird clade", the Plotopteridae has been recovered either as a sister taxon to Suloidea (Sulidae + Anhingidae + Phalacrocoracidae; Mayr et al., 2015) or within Suloidea as a sister to the cormorant-darter clade (Anhingidae + Phalacrocoracidae; Smith, 2010). Nevertheless, support for relevant nodes is rather weak, and a minor modification of character scorings may result in a drastic change in topology (see Mayr et al., 2015). Higherlevel relationships of the family should be considered tentative, until more anatomical information on these birds is available.

Since 1969, plotopterids have been discovered on both sides of the North Pacific Ocean. The great majority of plotopterid fossils are more than an order of magnitude larger than $P$. joaquinensis but are about the same age or somewhat older (Table 1). Undescribed examples of smaller plotopterids have been reported from Japan (Olson and Hasegawa, 1996).

Plotopterid coracoids, when preserved, are consistently long and slender and comparable to the shape of RBCM.EH2014.032.0001.001. In cases where the forelimbs have been preserved, they exhibit penguin-like adaptations for underwater, wing-propelled locomotion (Hasegawa et al., 1979; Olson and Hasegawa, 1979, 1996; Olson, 1980; Kimura et al., 1998; Mayr, 2005; Sakurai et al., 2008; Dyke et al., 2011).

The discovery of a complete coracoid is fortuitous because this bone lies at the focus of the stresses generated by forelimb-powered locomotion in birds. As a consequence, it exhibits more distinctive structural features than other bones. We compared RBCM.EH2014.032.0001.001 to examples from other avian families and to other members of the Family Plotopteridae.

\section{MATERIALS AND METHODS}

\section{Stratigraphic and Paleogeographic Setting}

The new coracoid was collected northwest of Sooke, British Columbia, (Area D of Figure 4) in beach exposures of the upper Oligocene Sooke

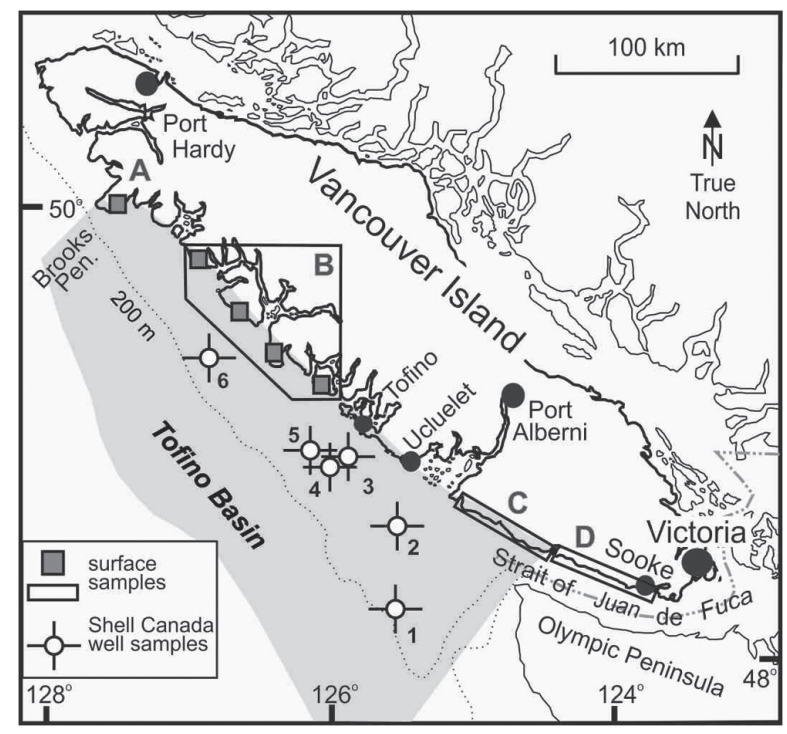

FIGURE 4. Map of Carmanah Group surface exposures along western Vancouver Island, British Columbia. A, Brooks Peninsula; B, Nootka (Tatchu Point, Nootka Island, Hesquiat Peninsula, and Flores Island); C, Carmanah (Pachena Point south to Owen Point); and D, Sooke (Port Renfrew south to Sooke) (for additional information, see Johns et al., 2012, figure 1).

Formation, Carmanah Group rocks (Figure 5). Similar strata are exposed along western Vancouver Island from Sooke to the Brooks Peninsula (Jeletzky, 1954; Cameron, 1980; Muller et al., 1981; Smyth, 1997). They lie within various subbasins of the Tofino Basin, have comparable upper Eocene to upper Oligocene units and microfaunas in the offshore, are associated with either the Pacific Rim or Crescent terrane, and may involve more than one tectonic or geologic event that resulted in their uplift and exposure along the coastline (Johns et al., 2012). Sandstone cliffs and sediment blocks, where the bird fossils were discovered, commonly show in-filled burrows near the section base, sand ripples, pebble conglomerate, concretionary and coquina-like shell-rich beds, cross-stratified sandstone and shell layers, and other fossil-rich intervals (Figure 6), which indicate a near shore environment (Bream, 1987).

Shallow marine facies of the Sooke Formation at southwestern Vancouver Island are correlated with a reversed magnetozone and $\mathrm{Chron} \mathrm{C} 6 \mathrm{Cr}$ (latest Oligocene ages, 24.1-24.8 Ma) (Prothero et al., 2008). The Sooke Formation rocks are temporally comparable to the Pysht Formation (23.7$30.5 \mathrm{Ma}$ ) in western Washington (e.g., Muller et al., 1981; Brandon et al., 1998; Prothero et al., 2001, 2008) and the Pyramid Hill Sand Member of the 


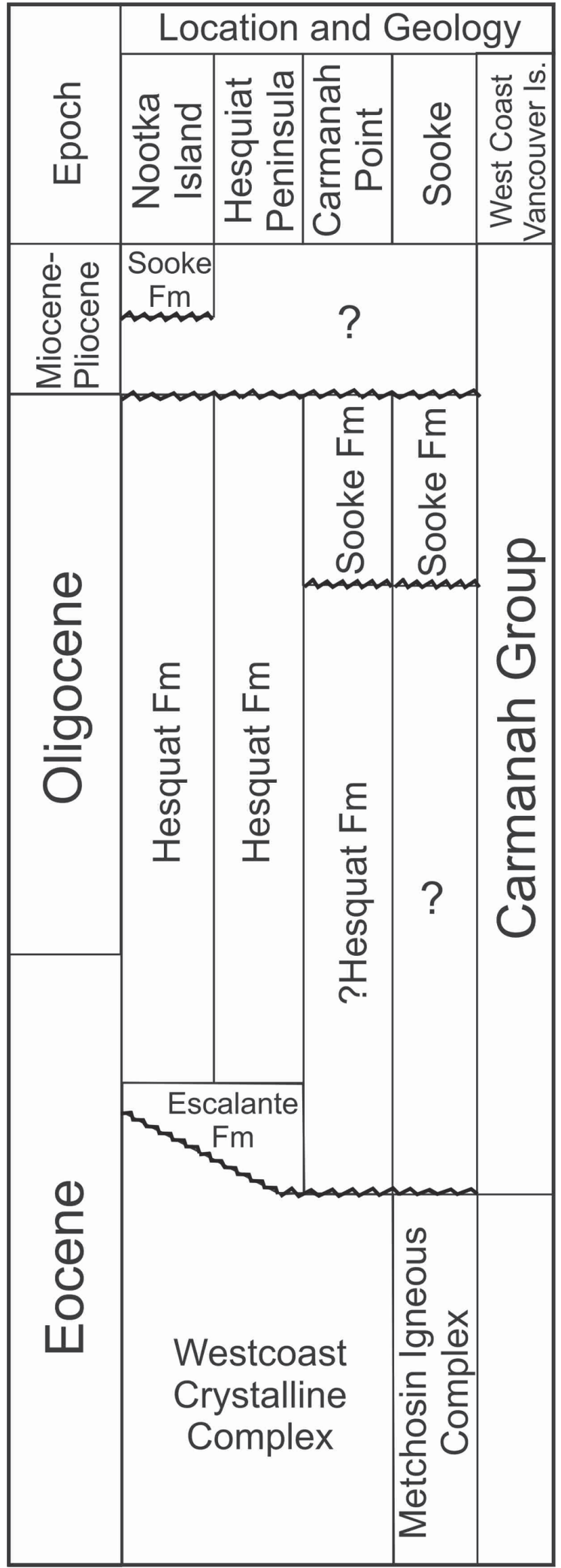

FIGURE 5. Geological context of the Sooke Formation and Carmanah Group rocks, Vancouver Island based on data from Clark and Arnold (1923), Cameron (1980), Muller et al. (1981), Johns et al. (2012).
Jewett Sand (24-25 Ma) in California (Scheirer and Magoon, 2007). These and other Cenozoic sediments were deposited in a fore-arc basin as the Farallon plate (Juan de Fuca plate) subducted beneath the North America plate (e.g., Hyndman et al., 1990; Snavely and Wells, 1996; Brandon et al., 1998).

The only comprehensive study of Sooke Formation macrofossils was produced by Clark and Arnold (1923). The majority of these fossils were found at beach exposures northwest of Sooke. Examples of diverse inshore invertebrates include gastropods, bivalves, nautiloids, tubeworms, barnacles, brachiopods, echinoderms, and coral. Common to the interval are the gastropods Bruclarkia acuminata (Anderson and Martin, 1914), Polinices sookensis Clark and Arnold, 1923, Molopophorus fishii Gabb, 1869, Molopophorus newcombei (Merriam, 1897), and the bivalve Saxidomus newcombei (Merriam, 1897). Vertebrate material is uncommon but diverse. It includes teeth of a desmostylian Cornwallius sookensis (Cornwall, 1922); (Beatty, 2006) and whale vertebrae, ribs, teeth, and other bone fragments. Plant macrofossils consist of isolated leaves, wood, and carbonaceous layers. Some of the wood shows evidence of boring by mollusks or worms. Upper Oligocene and lower Miocene strata of the Clallam and overlying Pysht formations in Washington State have produced fossils of early whales, pinnipeds, several genera of herbivorous desmostylids, and the "sea bear", Kolponomos clallamensis Stirton, 1960. Those strata have also produced fossils of the plotopterid genera Tonsala and Phocavis and other seabirds (e.g., Olson, 1980; Domning et al., 1986; Goedert, 1988; Barnes et al., 1994, 2001; Ray et al., 1994; Tedford et al., 1994; Goedert and Barnes, 1996; Barnes and Goedert, 2001; Goedert and Cornish, 2002).

\section{Material and Depositories}

$\mathrm{KMNH}$, Kitakyushu Museum of Natural History and Human History, Japan; LACM, Natural History Museum of Los Angeles County, California, USA; NHMUK, Natural History Museum, Tring, UK; RBCM, Royal British Columbia Museum, Victoria, British Columbia, Canada; SMF Senckenburg Research Institute and Natural History Museum, Frankfurt am Main, Germany; USNM, National Museum of Natural History, Smithsonian Institution, Washington, DC, USA; UWBM, Burke Museum of Natural History and Culture, University of Washington, Seattle, Washington, USA. 

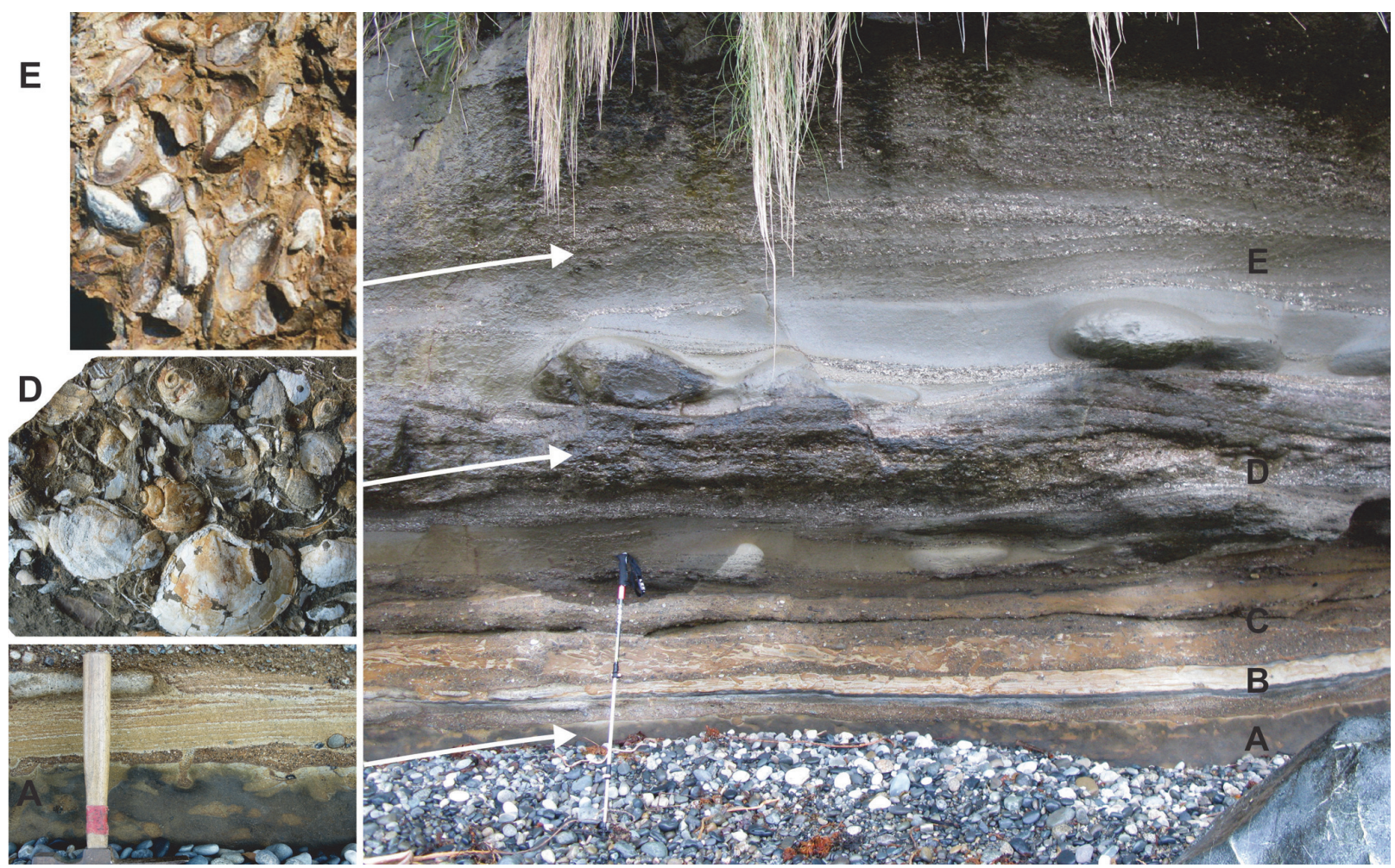

FIGURE 6. Cliff-beach exposure of the Sooke Formation. Letters indicate A, sandstone and shell-rich beds with burrows near the base; $\mathrm{B}$, ripples; $\mathrm{C}$, pebble conglomerate and shells; $\mathrm{D}$, shell-rich coquinas and concretions; and $\mathrm{E}$, Mytilus sp. and other shelly materials in cross-laminated and bedded sandstones. Rock hammer $26 \mathrm{~cm}$, walking stick $115 \mathrm{~cm}$.

RBCM.EH2014.032.0001.001 (Figures 1-3) consists of an isolated right coracoid found on the exposed face of a large block of medium- to coarse-grained sandstone. Before preparation, it was partially embedded in a matrix-supported shell coquina about $6 \mathrm{~cm}$ similar to unit $D$ in Figure 6 . This talus block was found on the beach close to the strata exposed at the high tide line and had been partially abraded by wave action. Initially, only the dorsal surface was exposed but it was loosened from the matrix with a $10-25 \%$ solution of acetic acid over a period of four hours. When the fossil was removed from the matrix, it separated into five pieces, revealing the bone's internal structure (Figure 2). The pieces were reassembled and glued together with Paraloid B-72.

An initial identification of RBCM.EH2014. 032.0001.001 was based on determining the presence of the two diagnostic characters mentioned by Howard (1969) and by comparing its proportional dimensions to extant families in the collections of the Royal BC Museum (RBCM) and in the Cowan Vertebrate Collection, Beatty Museum, University of British Columbia (Table 1). It was also compared to published descriptions of plotopterid fossils (Howard, 1969; Hasegawa et al., 1979; Olson, 1980; Olson and Hasegawa, 1996; Kimura et al., 1998; Mayr, 2005; Sakurai et al., 2008; Dyke et al., 2011), to previously described specimens including types (UWBM 86869, 86871, LACM 8927, KMNH 200006, and USNM 256518), and to casts of fossils from the Oligocene Ashiya Group of Kitakyushu, Japan, held in USNM (Figure 7).

Osteological descriptions of RBCM.EH2014. 032.0001 .001 follow the nomenclature used by Howard (1929) and Baumel and Witmer (1993). The extremities of the coracoid containing the processus acrocoracoideus and crista articularis sternalis are referred to as the "omal" (shoulder) and "sternal" ends, respectively.

\section{SYSTEMATIC PALEONTOLOGY}

Class Aves Linnaeus, 1758

Family Plotopteridae Howard, 1969

Remarks. Known genera of the Plotopteridae include Copepteryx Olson and Hasegawa, 1996; Hokkaidornis Sakurai et al., 2008; Phocavis Goedert, 1988; Plotopterum Howard, 1969; Ton- 
Kaiser, Watanabe, \& Johns: Plotopterid in Canada

TABLE 1. Temporal and geographic record of the Family Plotopteridae.

\begin{tabular}{|l|l|l|l|}
\hline \multicolumn{1}{|c|}{ Genus and species } & \multicolumn{1}{|c|}{ Formation and location } & \multicolumn{1}{c|}{ Age } & \multicolumn{1}{c|}{ Source } \\
\hline Plotopterum joaquinensis & $\begin{array}{l}\text { Pyramid Hill Sand M., Jewett Sand F., } \\
\text { California }\end{array}$ & $\begin{array}{c}\text { Late Oligocene } \\
\text { (24-25 Ma) }\end{array}$ & $\begin{array}{l}\text { Howard (1969), Scheirer and } \\
\text { Magoon (2007) }\end{array}$ \\
\hline Plotopterum sp. & Yamanouchi M., Akeyo F., Japan & $\begin{array}{c}\text { Early Miocene } \\
\text { (16-17 Ma) }\end{array}$ & $\begin{array}{l}\text { Olson and Hasegawa (1985), Sasao } \\
\text { et al. (2011) }\end{array}$ \\
\hline Tonsala hildegardae & Pysht F., Washington & $\begin{array}{c}\text { Early Oligocene } \\
\text { T. buchanani }\end{array}$ & $\begin{array}{l}\text { Olson (1980), Goedert and Cornish } \\
\text { (2002) }\end{array}$ \\
\hline Tonsht F., Washington & $\begin{array}{c}\text { Early Oligocene } \\
\text { Late Eocene } \\
\text { (ca. 34-35.3 Ma) } \\
\text { to early Oligocene }\end{array}$ & $\begin{array}{l}\text { Goedert and Cornish (2002), Dyke et } \\
\text { al. (2011) }\end{array}$ \\
\hline Stemec suntokum & Yamaga F., Japan & $\begin{array}{c}\text { Early Oligocene } \\
\text { (ca. 30-32 Ma) }\end{array}$ & $\begin{array}{l}\text { Ozaki and Hamasaki (1991), Olson } \\
\text { and Hasegawa (1996) }\end{array}$ \\
\hline Copepteryx hexeris & Sooke F., British Columbia & $\begin{array}{c}\text { Late Oligocene } \\
\text { (24.1-24.8 Ma) }\end{array}$ & Prothero et al. (2008), this study \\
& $\begin{array}{l}\text { Yamaghima F. ( Yamaga F.), Japan } \\
\text { Asagai F., Japan }\end{array}$ & $\begin{array}{c}\text { Early Oligocene } \\
\text { Early Oligocene } \\
\text { (ca. 30-32 Ma) } \\
\text { Early Oligocene }\end{array}$ & $\begin{array}{l}\text { Ozaki and Hamasaki (1991), Okada } \\
\text { (1992), Olson and Hasegawa (1996), } \\
\text { Kurita (2004) }\end{array}$ \\
\hline C. titan & Ainoshima F. ( Yamaga F.), Japan & $\begin{array}{l}\text { Early Oligocene } \\
\text { Eate Oligocene } \\
\text { (24-29 Ma) }\end{array}$ & Olson and Hasegawa (1996) \\
\hline Hokkaidornis abashiriensis & Tokoro F., Japan & $\begin{array}{l}\text { Late Eocene } \\
\text { (ca. 33.8 Ma) }\end{array}$ & $\begin{array}{l}\text { Goedert (1988), Goedert and Cornish } \\
\text { (2002) }\end{array}$ \\
\hline Phocavis maritimus & Keasey F., Oregon & (2008) \\
\hline
\end{tabular}

sala Olson, 1980. We propose Stemec as a new genus.

The fossil of RBCM.EH2014.032.0001.001 is a nearly complete coracoid (Figure 1) that preserves the acrocoracoid, the facies articularis humeralis (FAHU), the facies articularis clavicularis (FACL), the triosseal canal, and the main body of the shaft, including the crista intermedia and a deep fossa, omal to the sternal articulation. The facies articularis scapularis (FASC) and the extremity of the procoracoid have been lost to erosion.

When compared to examples from extant families, the overall shape of the Sooke fossil exhibits discrete characters described by Olson (1980) as typical of "pelecaniform" birds, including the "large, flat furcular facet" and the absence of a foramen associated with the procoracoid. The omal part of the sulcus $\mathrm{m}$. supracoracoidei is excavated to form a triangular depression whose margin is the medial extension of facies articularis clavicularis and tuberculum brachiale. A comparable triangular depression appears in modern members of the Anhingidae and Phalacrocoracidae, but is absent from Sulidae and many other groups of waterbirds, including the Gaviidae, Procellariidae, Ardeidae, and from wing-propelled divers such as the Spheniscidae and Alcidae.
RBCM.EH2014.032.0001.001 also exhibits derived character states for the Plotopteridae, allowing the referral of the new genus to this family. The most prominent characters include the convex and swollen caudal area of the triosseal canal (Howard, 1969; Olson, 1980; Smith, 2010: character 176:1), and strong omo-medial development (or eversion) of the FACL, which is evident as an abrupt protrusion from the shaft in dorsal and medial aspects (Figure 1.2, 1.4; see Olson, 1980; Smith, 2010, character 178:1).

In addition, the shaft of the coracoid is shallow dorsoventrally in Plotopteridae; the ratio of dorsoventral depth to mediolateral width of the shaft, measured just sternal (caudal) to the procoracoid, is less than 1.0 (confirmed in Copepteryx hexeris, Tonsala hildegardae, Plotopterum joaquinensis and in RBCM.EH2014.032.0001.001). This same ratio is greater than 1.0 , and typically near 1.2 , in members of the Recent Sulidae, Anhingidae, and Phalacrocoracidae (confirmed in 140 individuals from 16 phalacrocoracid species). The only exception occurred in Phalacrocorax melanoleucos where one of the 11 individuals examined showed a ratio of 0.93 . The coracoid in the Plotopteridae is also characterized by its extreme slenderness (Olson, 1980), as is evident from the ratio of mediolateral width of sternal articulation to the overall length (see below). 


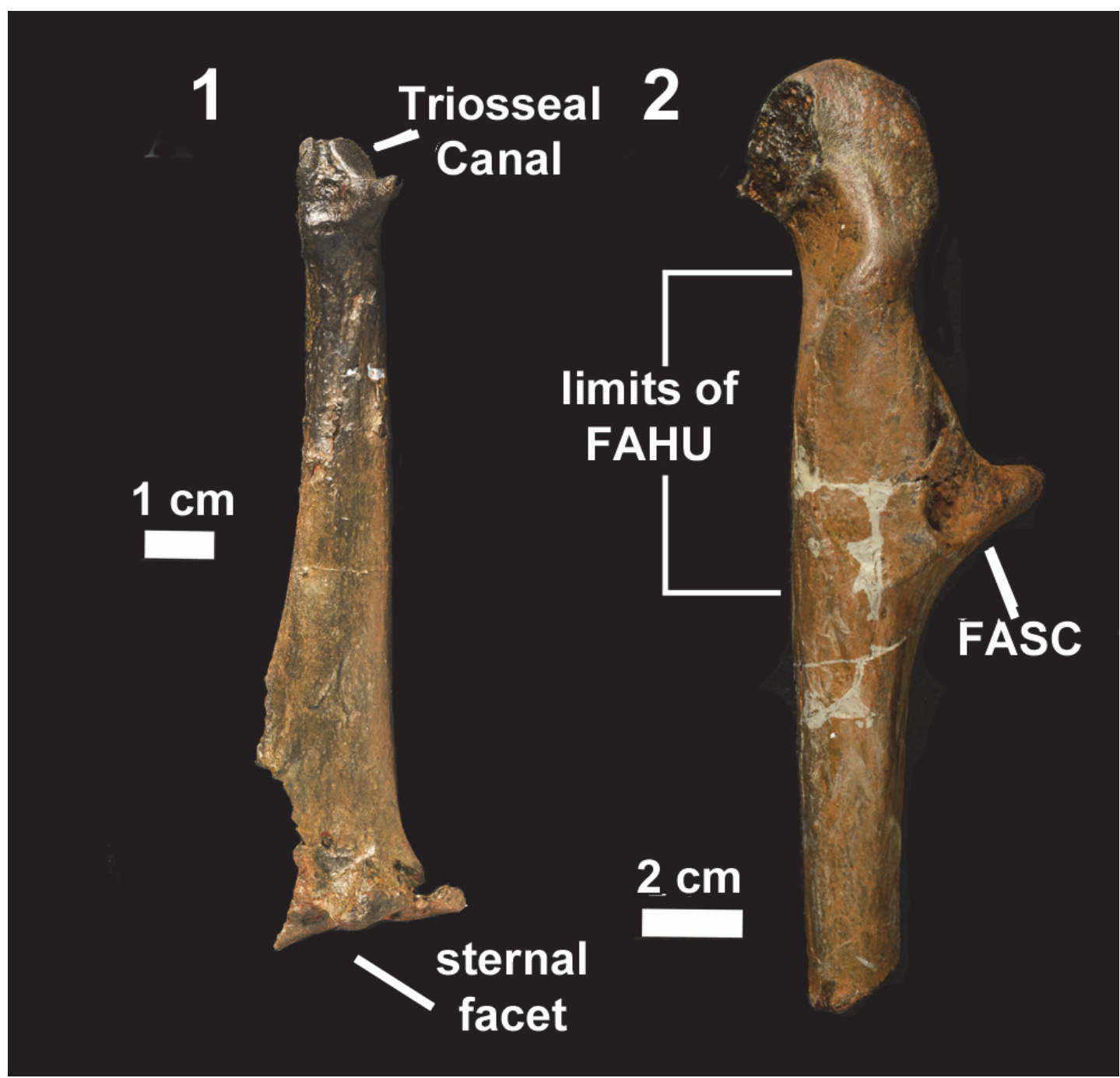

FIGURE 7. Casts of coracoids in the Smithsonian Institution, Washington DC, referable to Copepteryx, one of the very large plotopterids from the Oligocene Ashiya Group of Kitakyushu, Japan. 1, Dorsal aspect of shaft lacking the omal portion and 2, Isolated omal portion, ventral aspect. Abbreviations: FASC, facies articularis scapularis; see Figure 1 for others.

Stemec gen. nov.

zoobank.org/461C8F1F-BC36-4440-B290-62FCF65B7F02

Stemec suntokum gen. et sp. nov.

Figures 1-3

zoobank.org/219EFACE-F379-431B-9FA9-31DBBC981D21

Etymology. Stemec derived from a generic word for long-necked, black waterbird in the Coast Salish language, originally spoken in the type locality (Mitchell, 1968; Montler, 1991). We consider it neuter. The species name, suntokum, is derived from the family name of Leah and Graham Suntok, who found the specimen and donated it to the Royal BC Museum. Suffx '-um' is used here for a third declension, genitive plural, non-Latin consonant root.

Holotype. RBCM.EH2014.032.0001.001, a nearly complete right coracoid, missing only the procoracoid and small areas of the acrocoracoid. The dorsolateral surface of the shaft has been eroded. Stratigraphic position: Sooke Formation, Carmanah Group. Age: Late Oligocene. Collected on 28 December 2013 by Leah and Graham Suntok and deposited in the Royal BC Museum, 675 Belleville Street, Victoria, BC, Canada V8W 9W2.

Differential Diagnosis. Stemec differs from most other plotopterids in its small size. Only Plotopterum joaquinensis Howard, 1969 is a plotopterid of similar size. Stemec differs from 
Plotopterum in the following features: the FAHU is a raised, flat platform, omal to the procoracoid with clearly demarcated lateral and sternal margins that are strongly elevated from the shaft (in Plotopterum, the FAHU is not raised from the shaft; Figure 3.1, 3.2); and the sulcus $\mathrm{m}$. supracoracoidei forms a shallow depression pointing omally (Figure 3.4), but does not become the prominent, steepwalled groove seen in Plotopterum (Figure 3.3). Apart from much smaller size, Stemec differs from larger plotopterids in: the FAHU lies omal to the procoracoid (in Copepteryx and Tonsala, the FAHU extends beyond the procoracoid); the shaft widens more gradually towards the sternal articulation (Figure 1) than in Copepteryx and Hokkaidornis (see Olson and Hasegawa, 1996; Sakurai et al., 2008); the facies articularis sternalis faces relatively medially (in Copepteryx and Hokkaidornis, it is almost perpendicular to shaft in dorsal view); and the facies interna is wide omo-sternally with the omo-dorsal lip lying omal to the crista intermedia (Figures 1.1, 2.3) (in Copepteryx and Hokkaidornis, the facies interna is restricted near the crista intermedia).

Age, Locality and Stratigraphic Units. Late Oligocene near Sooke, at the southern end of Vancouver Island, British Columbia, Canada; Carmanah Group, Sooke Formation.

Comparative Anatomy. The only known coracoid from a plotopterid of comparable size to Stemec is the omal fragment of Plotopterum joaquinensis Howard, 1969 (LACM 8927). Coracoids of Copepteryx hexeris Olson and Hasegawa, 1996, Hokkaidornis abashiriensis Sakurai et al., 2008, Tonsala hildegardae Olson, 1980, and $T$. buchanani Dyke et al., 2011 are distinctly larger. No coracoid is known for either $C$. titan Olson and Hasegawa, 1996 or Phocavis maritimus Goedert, 1988, but other preserved elements indicate that those species were also very large.

Major osteological features tend to vary among the Plotopteridae and Stemec differs from other genera, including Plotopterum. The triangular depression on the medial side of the acrocoracoid, between the FACL and the tuberculum brachiale, is particularly variable. In Plotopterum it extends omally to form a "deep, triangular groove" which reaches the omal end of acrocoracoid (see also Howard, 1969). In Tonsala and Stemec (and also in Phalacrocorax), the groove is much less developed omally (Figure 3.2), and the omal apex of the depression lies roughly at the center of the medial surface of acrocoracoid. In Copepteryx, the overall structure lies dorsally with the apex of its margin pointing dorsally.

The FACL in both Plotopterum and Stemec is almost circular and unlike the rather oblong structure in Tonsala. In both Plotopterum and Stemec the FAHU is oval, relatively short longitudinally, and its sternal margin is clearly marked and elevated from the shaft but in Tonsala and Copepteryx, the FAHU is elongated, extending sternally over the base of procoracoid, and its caudal portion lies almost flush with the surface of the shaft (Figure 7.1, 7.2).

In Stemec, the facies interna of crista articularis sternalis (sternal facet) lies at a right angle to the shaft and extends omally. Its omo-dorsal margin is marked by an overhanging ridge that is separated from the crista intermedia by a deep fossa. In Copepteryx and Tonsala (?) sp. (Olson and Hasegawa, 1996), and in Hokkaidornis, the facies interna is restricted sternally. In Copepteryx the crista articularis sternalis forms a right angle with the shaft in dorsal view, differing from that in Ste$m e c$ where it slopes medially as in most other waterbirds, including sulids, phalacrocoracids, and anhingids.

Description. Total length $74.8 \mathrm{~mm}$; maximum width at the sternal articulation $12.8 \mathrm{~mm}$; length of the head $24.0 \mathrm{~mm}$. The FACL is nearly circular, 5.2 by $6.6 \mathrm{~mm}$. The FAHU is an oval, 10.1 by $7.8 \mathrm{~mm}$. Mediolateral width and dorsoventral depth of shaft measured just sternal to procoracoid, 6.8 and 6.5 $\mathrm{mm}$, respectively. Distance across sternal articulation, from omal to sternal margin, $6.1 \mathrm{~mm}$. The ratio of the sternal articulation to overall length in Ste$m e c$ is 5.8 , exceeding the minimum criterion for "exceptionally elongate," set by Livezey and Zusi (2006, character 1292), by $45 \%$ (Table 2).

Small areas on the omal surface of the acrocoracoid have been eroded without significant damage, however, erosion has removed the procoracoid, facies articularis scapularis (FASC) (Figure 1.1), and the processus lateralis at the sternal end. The medial margin and the sternal articulation are preserved and appear to be complete.

Overall, the surface of the shaft is smooth, as expected in an adult bird, and there are no rugose areas to suggest the presence of un-ossified cartilaginous structures that might be found in juvenile birds. The length of the coracoid is slightly greater than the largest Recent cormorants (e.g., Phalacrocorax carbo). All other plotopterids, except Plotopterum joaquinensis, are distinctly larger than Stemec suntokum. The shaft retains convex dorsal and ventral surfaces throughout its length. 
TABLE 2. Proportional dimensions of coracoids among the Plotopteridae and modern waterbirds.

\begin{tabular}{|c|c|c|c|}
\hline Taxa & Source & $\begin{array}{l}\text { Length of head1 } \\
\text { to total length } \\
(\%)\end{array}$ & $\begin{array}{l}\text { Width of sternal } \\
\text { articulation to } \\
\text { total length (\%) }\end{array}$ \\
\hline \multicolumn{4}{|c|}{ Plotopteridae } \\
\hline Stemec suntokum & RBCM.EH2014.032.0001.001 & 23.3 & 18.0 \\
\hline Copepteryx hexeris & Hasegawa et al. (1979) & 23.5 & 23.0 \\
\hline Tonsala(?) sp. & Hasegawa et al. (1979) & 21.5 & 21.0 \\
\hline \multicolumn{4}{|c|}{ Sulidae } \\
\hline Sula sula & RBCM 23425 & 29.3 & 46.0 \\
\hline \multicolumn{4}{|c|}{ Anhingidae } \\
\hline Anhinga anhinga & UWBM 40957 & 23.6 & 26.0 \\
\hline A. melanogaster & UWBM 62930 & 24.7 & 24.0 \\
\hline \multicolumn{4}{|c|}{ Stem cormorants } \\
\hline Oligocorax sp. & Mayr (2015) & 25.3 & 27.0 \\
\hline Nambashag billerooensis & Worthy (2011) & 25.6 & 23.9 \\
\hline \multicolumn{4}{|c|}{ Phalacrocoracidae } \\
\hline \multirow[t]{3}{*}{ Phalacrocorax harrisi } & Shufeldt (1915) & 16.4 & 31.0 \\
\hline & NHMUK 1973.1.13 & 13.45 & 30.0 \\
\hline & NHMUK 1902.1.9.12 & 15.35 & 32.0 \\
\hline \multirow[t]{2}{*}{ Phalacrocorax penicillatus } & RBCM 15002 & 25.7 & 24.0 \\
\hline & RBCM 12071 & 25.6 & 25.0 \\
\hline P. pelagicus & RBCM 23169 & 25.5 & 30.0 \\
\hline$P$. auritus & RBCM 11279 & 24.3 & 28.0 \\
\hline \multicolumn{4}{|c|}{ Spheniscidae } \\
\hline Eudyptula minor & UWBM 57505 & 30.0 & 29.0 \\
\hline Spheniscus magellanicus & Livezey and Zusi (2006) & 22.9 & 29.0 \\
\hline Spheniscus humboldti & UWBM 57504 & 28.7 & 32.0 \\
\hline Pygoscelis antarctica & UWBM 38043 & 34.9 & 34.0 \\
\hline
\end{tabular}

The FACL is a clearly marked circular facet in both Stemec and Plotopterum. It is oblong in Tonsala, but its morphological details are not clearly observable in other plotopterids. In Plotopteridae, the FACL is directed medioventrally as in Sulidae, rather than ventrally as in the Phalacrocoracidae. The impressio ligamenti acrocoracohumeralis is well marked in Stemec, Plotopterum, and Copepteryx, with a shallow but clear longitudinal sulcus running between its medial and lateral margins (see also Smith, 2010, character 169:1). It is not observable in Tonsala, but this may be due to poor preservation in the available specimens.

In Plotopterum, as well as in Recent Phalacrocoracidae, the sternodorsal portion of FAHU lies at the base of procoracoid and is strongly elevated from the shaft, whereas the omal portion lies on the laterodorsal surface of shaft omal at the base of procoracoid. The caudal margin of the omal portion is clearly marked and slightly elevated from the shaft. Howard (1969) apparently refers to the sternodorsal portion as the "scapular facet" but it appears to be a part of FAHU as in Recent Phalacrocoracidae. Probably the FASC of Plotopterum was either indistinct (as in Phalacrocoracidae), or has been lost along with the tip of the procoracoid. As noted above, the FAHU is longitudinally elongated in Copepteryx and Tonsala, where the sternal margin extends over the base of procoracoid. At that point it is indistinct and barely elevated from the shaft. In the latter two genera, FASC is well developed as a cup-like cotyla scapularis lying on the base of the procoracoid (see also Olson, 1980; Olson and Hasegawa, 1996; Dyke et al., 2011). In most aspects of FAHU and FASC, Stemec is similar to Plotopterum, although the sternodorsal portion of FAHU and FASC are likely to have been largely abraded away. In Plotopteridae, the dorso- 
medial margin of the FAHU forms a thick lip over a longitudinal groove on the dorsal margin of the triosseal canal (see also Howard, 1969; Olson, 1980), which is somewhat less prominent in Copepteryx and Tonsala.

The shaft sternal to the procoracoid is semicircular in cross-section (Figure 2.1), and slightly compressed dorsoventrally as in most other plotopterids, rather than compressed mediolaterally as in their relatives, including sulids, phalacrocoracids, and anhingids (see above). In Copepteryx the shaft is rather strongly compressed dorsoventrally. In Plotopteridae, the medial and lateral margins of the mid-shaft region are rather straight.

On the sternal end of the Stemec coracoid, facies interna of crista articularis sternalis extends omally, and its omo-dorsal margin is prominently marked by an overhanging ridge as in sulids, phalacrocoracids, and anhingids, but the cranial extension is slightly more pronounced. In other plotopterids where the sternal end of the coracoid is well preserved (Copepteryx hexeris and Hokkaidornis abashiriensis), the sternal facet is quite narrow omo-sternally, with the omo-dorsal margin lying only slightly omal to the crista intermedia (the sternal margin of facet) (Figure 2.3) (see also Olson and Hasegawa, 1996, figure 1; Sakurai et al., 2008, figure 3). This feature is apparently unique to Stemec among known plotopterids, although it is not certain whether the feature is an apomorphy of the genus within the family or a plesiomorphically retained character.

\section{DISCUSSION}

The structure of avian coracoids is easily recognizable and apparent in both Mesozoic birds (e.g., Chiappe, 2002; Hope, 2002; Zhou and Hou, 2002; Agnolin, 2010) and modern avian families. The omal portion of the shaft is often slender but as it approaches the sternum, it increases in width and develops a broadly concave dorsocaudal surface. The width of the articular surface helps to disperse forces generated by forelimb locomotion across the leading edge of the sternum and the concave dorsocaudal surface forms a smooth continuation with the interior surface of the sternum. The width of the concave surface is often enhanced by a broad lateral process that does not articulate with the sternum.

The long, narrow coracoids of plotopterids are exceptional within Class Aves and contrast sharply with the robust coracoids of other wing-propelled diving birds. Penguins are the only avian family to

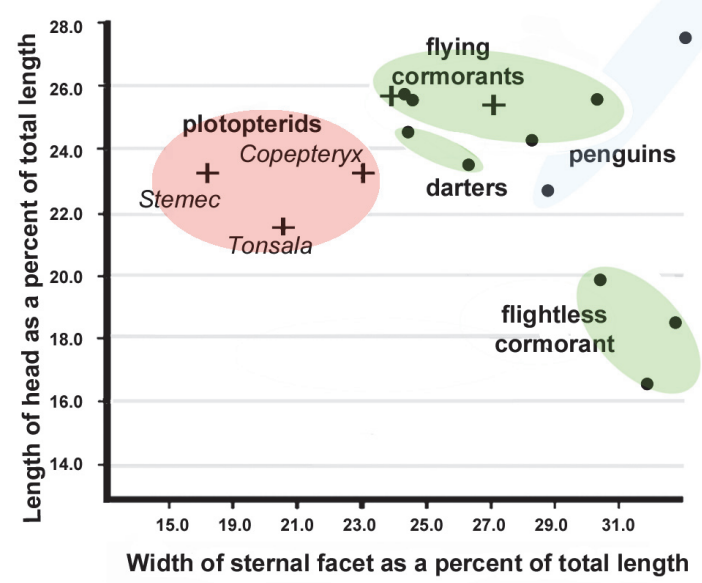

FIGURE 8. Dimensional proportions of the Stemec coracoid (RBCM.EH2014.032.0001.001) and to two much larger plotopterids compared to cormorants, darters, and penguins. All other families of wing-propelled birds have larger values on both axes. Extinct examples are marked by a '+' symbol.

have coracoids with elongated, cylindrical shafts that approach the condition in plotopterids but their bones also terminate in the broad, concave sternal articulation seen in other families. The coracoids of the flightless Great Auk (Pinguinus impennis) (see van Wijngaarden-Bakker, 1978), and its flighted relatives are robust somewhat similar to those of penguins.

The coracoids of cormorants, including Oligocorax sp. from the early Miocene of Germany (Mayr, 2015, figure 3) and Nambashag billerooensis from the late Oligocene of South Australia (Worthy, 2011, figure 2), are all very similar in form and proportional dimensions (Table 2, Figure 8). Even the coracoid of flightless Galapagos Cormorant (Phalacrocorax harrisi) retains a typically broad sternal end, similar to those of its flighted relatives. Only its omal portion is greatly reduced (Shufeldt, 1915; Livezey, 1992) (Table 2, Figure 7). Neither cormorants nor darters have coracoids that approach the extreme condition of Stemec (Table 2, Figure 8).

Although the coracoid of Stemec shares some characteristics with Plotopterum joaquinensis (Figure 3 ), several features of the omal end suggest that the two organisms used parts of the pectoral girdle in somewhat different ways. The FAHU is a prominent feature in both fossils, but in $P$. joaquinensis the extension onto the base of the procoracoid adds an additional $30 \%$ to its length. In Stemec, the FAHU is a robust plate implying that greater loads were exerted on its surface by move- 
ment of the humerus (Currey, 2002). Similarly, the FACL of Stemec (Figure 1.2, 1.4) is more robust and more domed than that of $P$. joaquinensis, again suggesting a more rigorous role for that joint in locomotion. The two species may have been similar in size, but variation in the shape of the articulating surfaces and the depression on the medial surface of the acrocoracoid that extends from the triosseal canal suggest that they represent discrete taxa.

Updated age information for plotopterid localities in California and Japan suggests that some plotopterids are older than previously thought (Table 1), but Stemec and Plotopterum are likely to have been near contemporaries on the west coast of North America (24-25 Ma).

\section{ACKNOWLEDGMENTS}

We wish to thank L. Suntok and G. Suntok for donating the fossil of Stemec to the Royal BC Museum. The authors depended heavily on the skeleton collection at the Royal BC Museum for comparative material from modern avian families but wish to thank R.C. Faucett and K. Eng for additional help with the collections at the University of Washington's Burke Museum that include some plotopterid material. M.G. Florence assisted with collections at the National Museum of Natural History, Smithsonian Institution, Washington DC, J.H. Cooper accommodated work on the collection at the Natural History Museum, Tring, England, T. Ohashi and Y. Okazaki helped us work on the collection of Kitakyushu Museum of Natural History and Human History, Japan, and I. Szabo and C. Stinson helped with the Cowan Vertebrate Collection, Beatty Museum, University of British Columbia, Vancouver, and P. Battley, Massey University, New Zealand, provided measurements of penguins. V.R. Rhue and S.A. McLeod, Department of Vertebrate Paleontology, Natural History Museum of Los Angeles County, provided access to the type specimen of Plotopterum and also contributed photographs of the specimen. Photographs of the Stemec coracoid were taken by the authors and by $\mathrm{N}$. Panter, volunteer, Royal BC Museum. This project was supported by operational funds made available by the Royal BC Museum. We would also like to thank two anonymous reviewers for useful comments that greatly helped to improve the content of the article.

\section{REFERENCES}

Agnolin, F.L. 2010. An avian coracoid from the Upper Cretaceous of Patagonia, Argentina. Studia Geologica Salmanticensia, 46:99-119.

Anderson, F.M. and Martin, B. 1914. Neogene record in the Temblor Basin, California, and Neogene deposits of the San Juan district, San Luis Obispo County. Proceedings of the California Academy of Science, Series 4, 4:15-112.

Barnes, L.G. and Goedert, J.L. 2001. Stratigraphy and paleoecology of Oligocene and Miocene desmostylian occurrences in western Washington State, U.S.A. Bulletin of the Ashoro Museum of Paleontology, 2:7-22.

Barnes, L.G., Goedert, J.L., and Furusawa, H. 2001. The earliest known echolocating toothed whales (Mammalia; Odontoceti): preliminary observations of fossils from Washington State. Mesa Southwest Museum Bulletin, 8:91-100.

Barnes, L.G., Kimura, M., Furusawa, H., and Sawamura H. 1994. Classification and distribution of Oligocene Aetiocetidae (Mammalia; Cetacea; Mysticeti) from western North America and Japan. Island Arc, 3:392431. doi:10.1111/j.1440-1738.1994.tb00122.x

Baumel, J.J. and Witmer, L.M. 1993. Osteologia, p. 45132. In Baumel J.J. (ed.), Handbook of Avian Anatomy: Nomina anatomica avium (Second Edition). Publications of the Nuttal Ornithological Club 23, Cambridge, Massachusetts.

Beatty, B.L. 2006. Rediscovered specimens of Cornwallius (Mammalia, Desmostylia) from Vancouver Island, British Columbia, Canada. PalArch's Journal of Vertebrate Palaeontology, 1:1-6.

Brandon, M.T., Roden-Tice, M.K., and Garver, J.I. 1998. Late Cenozoic exhumation of the Cascadia accretionary wedge in the Olympic Mountains, northwest Washington State. Geologic Association of America Bulletin, 110:985-1009.

Bream, S.E. 1987. Depositional environment, provenance, and tectonic setting of the Upper Oligocene Sooke Formation, Vancouver Island, B.C. Unpublished M.Sc. thesis, Department of Geology, Western Washington University, Seattle.

Cameron, B.E.B. 1980. Biostratigraphy and Depositional Environment of the Escalante and Hesquiat Formations (early Tertiary) of the Nootka Sound Area, Vancouver Island, British Columbia. Geological Survey of Canada Paper 78-9, 28 pp, Ottawa.

Chiappe, L.M. 2002. Osteology of the flightless Patagopteryx deferrariisi from the Late Cretaceous of Patagonia (Argentina), p. 281-316. In Chiappe L.M. and Witmer L.M. (eds.) Mesozoic Birds: Above the Heads of Dinosaurs. University of California Press, Berkeley.

Clark, B.L. and Arnold, R. 1923. Fauna of the Sooke Formation, Vancouver Island. University of California, Department of Geological Sciences Bulletin, 14:123234. 
Cope, E.D. 1894. On Cyphornis, an extinct genus of birds. Journal of the Academy of Natural Science of Philadelphia, Series 2, 9:449-451.

Cornwall, I.E. 1922 Some notes on the Sooke Formation, Vancouver Island, B.C. Canadian Field Naturalist, 36:121-123.

Currey, J.D. 2002. Bones: Structure and Mechanics. Princeton University Press, Princeton.

Domning, D.P., Ray, C.E., and McKenna, M.C. 1986. Two new Oligocene Desmostylians and a discussion of Tethytherian systematics. Smithsonian Contributions to Paleobiology, 59:1-56.

Dyke, G.J., Wang, X., and Habib, M.B. 2011. Fossil plotopterid seabirds from the Eo-Oligocene of the Olympic Peninsula (Washington State, USA): descriptions and functional morphology. PLOS ONE, 6(10):e25672. doi:10.1371/journal.pone.0025672

Gabb, W.M. 1869. Tertiary invertebrate fossils. Cretaceous and Tertiary fossils. California Geological Survey, Paleontology, 2:1-299.

Goedert, J.L. 1988. A new late Eocene species of Plotopteridae (Aves: Pelecaniformes) from northwestern Oregon. Proceedings of the California Academy of Sciences, 45:97-102. doi:10.1016/j.cretres.2006.05.001

Goedert, J.L. and Barnes, L.G. 1996. The earliest known odontocete; a cetacean with agorophiid affinities from latest Eocene to earliest Oligocene rocks in Washington State, p. 148. In Repetski, J.E. (ed.), Sixth North American Paleontological Convention, Paleontological Society Special Publication 8. Paleontological Society, Washington, DC.

Goedert, J.L. and Cornish, J. 2002. A preliminary report on the diversity and stratigraphic distribution of the Plotopteridae (Pelecaniformes) in Paleogene Rocks of Washington State, USA, p. 63-76. In Zhou, Z. and Zhang, F. (eds.), Proceedings of the 5th Symposium of the Society of Avian Paleontology and Evolution, Beijing, 1-4 June 2000. Science Press, Beijing.

Hasegawa, Y., Isotani, S., Nagai, K., Seki, K., Suzuki, T., Otsuka, H., Ota, M., and Ono, K. 1979. Preliminary notes on the Oligo-Miocene penguin-like birds from Japan (Parts I-VII). Bulletin of the Kitakyushu Museum of Natural History, 1:41-60. (In Japanese)

Hope, S. 2002. The Mesozoic radiation of Neornithes, p. 169-218. In Chiappe, L.M. and Witmer, L.M. (eds.), Mesozoic Birds: Above the Heads of Dinosaurs. University of California Press, Berkeley.

Howard, H. 1929. The avifauna of the Emeryville Shellmound. University of California Publications in Zoology, 32:301-394.

Howard, H. 1969. A new avian fossil from Kern County, California. Condor, 71:68-69.

Hyndman, R.D., Yorath, C.J., Clowes, R.M., and Davis, E.E. 1990. The northern Cascadia subduction zone at Vancouver Island: seismic structure and tectonic history. Canadian Journal of Earth Sciences, 27:313329. doi:10.1139/e90-030
Jeletzky, J.A. 1954. Tertiary Rocks of the HesquiatNootka Area, West Coast of Vancouver Island, British Columbia. Geological Survey of Canada, Paper 50-57, Canada Department of Mines and Technical Surveys, Ottawa.

Johns, M.J., Trotter, J.A., Barnes, C.R., and Narayan, Y.R. 2012. Biostratigraphic, strontium isotopic and geologic constraints on the landward movement and fragmentation of terranes with the Tofino Basin, British Columbia. Canadian Journal of Earth Sciences, 40:819-856. doi:10.1139/E2012-032

Kimura, M., Sakurai, K., and Katoh, T. 1998. An extinct fossil bird (Plotopteridae) from the Tokoro Formation (late Oligocene) in Abashiri City, northeastern Hokkaido, Japan. Journal of Hokkaido University of Education (Section IIB), 48:29-34 (11-16). (In Japanese)

Kurita, H. 2004. Paleogene dinoflagellate cyst biostratigraphy of northern Japan. Micropaleontology, 50(supplement 2):3-50.

Linnaeus, C. 1758. Systema naturae per regna tria naturae, secundum classes, ordines, genera, species, cum characteribus, differentiis, synonymis, locis. Tomus I. Editio decima, reformata. Holmiae, Laurentii Salvii. Stockholm. (In Latin)

Livezey, B.C. 1992. Flightlessness in the Galápagos cormorant (Compsohalieus [Nannopterum] harrisi): heterochrony, giantism, and specialization. Zoological Journal of the Linnean Society, 105:155-224.

Livezey, B.C. and Zusi, R.L. 2006. Higher-order phylogeny of modern birds (Theropoda, Aves: Neornithes) based on comparative anatomy: I. Methods and characters. Bulletin of the Carnegie Museum of Natural History, 37:1-556.

Mayr, G. 2005. Tertiary plotopterids (Aves, Plotopteridae) and a novel hypothesis on the phylogenetic relationships of penguins (Spheniscidae). Journal of Zoological Systematics and Evolutionary Research, 43:6171. doi:10.1007/bf00818163

Mayr, G. 2010. Paleogene Fossil Birds. Springer-Verlag, Berlin and Heidelberg.

Mayr, G. 2015. A new skeleton of the late Oligocene "Enspel cormorant" - from Oligocorax to Borvocarbo and back again. Paleobiology and Paleoenvironment, 95:87-101.

Mayr, G., Goedert, J.L., and Vogel, O. 2015. Oligocene plotopterid skulls from western North America and their bearing on the phylogenetic affinities of these penguin-like seabirds. Journal of Vertebrate Paleontology, 35(4):e943764. doi:10.1080/ 02724634.2014 .943764

Merriam, J.C. 1897. New species of Mollusca from Vancouver Island. Nautilus, 11:64-65.

Mitchell, M.R. 1968. A dictionary of Songish, a dialect of Straits Salish. Unpublished M.A. thesis, Department of Linguistics. University of Victoria, Victoria, British Columbia, Canada.

Montler, T. 1991. Saanich, North Straits Salish Classified Wordlist. Canadian Ethnology Service, Paper No. 
119 Mercury Series. Canadian Museum of Civilization, Ottawa.

Muller, J.E., Cameron, B.E.B., and Northcote, K.E. 1981. Geology and Mineral Deposits of Nootka Sound Map-area, Vancouver Island, British Columbia. Geological Survey of Canada Paper 80-16, Ottawa.

Okada, H. 1992. Calcareous nannofossils and biostratigraphy of the Paleogene sequences of the northern Kyushu, Japan. Journal of the Geological Society of Japan, 98:509-528.

Olson, S.L. 1980. A new genus of penguin-like pelecaniform bird from the Oligocene of Washington (Pelecaniformes: Plotopteridae). Natural History Museum of Los Angeles County Contributions in Science, 330:51-57.

Olson, S.L. and Hasegawa, Y. 1979. Fossil counterparts of giant penguins from the North Pacific. Science, 206:688-689. doi:10.1126/science.206.4419.688

Olson S.L. and Hasegawa, Y. 1985. A femur of Plotopterum from the early middle Miocene of Japan (Pelecaniformes: Plotopteridae). Bulletin of the National Science Museum, Tokyo, Series C, 11:137140.

Olson, S.L. and Hasegawa, Y. 1996. A new genus and two new species of gigantic Plotopteridae from Japan (Aves: Pelecaniformes). Journal of Vertebrate Paleontology, 16:742-751.

Ozaki, M. and Hamasaki, S. 1991. Fission track ages of the Paleogene strata in the northern part of Fukuoka Prefecture, Southwest Japan. Journal of the Geological Society of Japan, 97:251-254. (In Japanese)

Prothero, D.R., Draus, E., Cockburn, T.C., and Nesbitt, E.A. 2008. Paleomagentism and counterclockwise tectonic rotation of the Upper Oligocene Sooke Formation, southern Vancouver Island, British Columbia. Canadian Journal of Earth Sciences, 45, 499-507.

Prothero, D.R., Streig, A., and Burns, C. 2001. Magnetic stratigraphy and tectonic rotation of the Upper Oligocene Pysht Formation, Clallam County, Washington, p. 226-235. In Prothero, D.R. (ed.), Magnetic Stratigraphy of the Pacific Coast Cenozoic. Pacific Section SEPM (Society for Sedimentary Geology), No. 91. Tulsa.

Ray, C.E., Domning, D.P., and McKenna, M.C. 1994. A new specimen of Behemotops proteus (Order Desmostylia) from the marine Oligocene of Washington. Proceedings of the San Diego Museum of Natural History, 29:205-222.

Russell, L.S. 1968. A new cetacean from the Oligocene Sooke Formation of Vancouver Island, British Columbia. Canadian Journal of Earth Sciences, 5:929-933.

Sakurai, K., Kimura, M., and Katoh, T.A. 2008. New penguin-like bird (Pelecaniformes: Plotopteridae) from the Late Oligocene Tokoro Formation, northeastern Hokkaido, Japan. Oryctos, 7:83-94.

Sasao, E., Danhara, T., Iwano, H., and Hayashi, J. 2011. Fission track ages of the Miocene Mizunami and
Iwamura Groups in southeastern Gifu Prefecture, Central Japan. Journal of the Geological Society of Japan, 117:476-481. (In Japanese with English abstract)

Scheirer, A.H. and Magoon, L.B. 2007. Age, Distribution, and Stratigraphic Relationship of Rock Units in the San Joaquin Basin Province, California, p. 1-107. In Scheirer, A.H. (ed.), Petroleum Systems and Geologic Assessment of Oil and Gas in the San Joaquin Basin Province California. US Geological Survey Professional Paper, 1713, Washington, DC.

Shufeldt, R.W. 1915. Comparative osteology of Harris's flightless cormorant (Nannopterum harrisi). Emu, 15:36-113.

Smith, N.D. 2010. Phylogenetic analysis of Pelecaniformes (Aves) based on osteological data: implications for waterbird phylogeny and fossil calibration studies. PLoS ONE, 5(10): e13354. doi:10.1371/journal.pone.0013354

Smyth, W.R. 1997. Bedrock Geology of Brooks Peninsula, p. 21-28. In Hebda, R.H. and Haggarty, J.C. (eds.), Brooks Peninsula: An Ice Age Refugium on Vancouver Island. Occasional Paper No. 5, British Columbia Ministry of Environment, Lands, and Parks, Victoria.

Snavely, P.D. Jr. and Wells, R.E. 1996. Cenozoic evolution of the continental margin of Oregon and Washington, p. 161-182. In Rogers, A.M., Walsh, T.J., Kockelman, W.J., and Priest, G.R. (eds.), Assessing Earthquake Hazards and Reducing Risk in the Pacific Northwest. U.S. Geological Survey Professional Paper 1560, 1, Washington, DC.

Stirton, R.A. 1960. A marine carnivore from the Clallam Miocene Formation, Washington: its correlation with nonmarine Faunas. University of California Publications in Geological Sciences, 36(7):345-368.

Tedford, R.H., Barnes, L.G., and Ray, C. 1994. The Early Miocene littoral ursoid carnivoran Kolponomos: systematics and mode of life. Proceedings of the San Diego Society of Natural History, 29:11-32.

van Wijngaarden-Bakker, L.H. 1978. A subfossil Great Auk - Pinguinus impennis (L.) from the Netherlands. Ardea, 66:57-61.

Wetmore, A. 1928. The systematic position of the fossil bird Cyphornis magnus, p. 1-4. In Contributions to Canadian Palaeontology, Geological Survey of Canada, Museum Bulletin No. 49, Ottawa.

Worthy, T.H. 2011. Description and phylogenetic relationships of a new genus and two new species of OligoMiocene cormorants (Aves: Phalacrocoracidae) from Australia. Zoological Journal of the Linnean Society, 163:277-314.

Zhou, Z. and Hou, L. 2002. The discovery and study of Mesozoic birds in China, p. 160-183. In Chiappe, L.M. and Witmer, L.M. (eds.), Mesozoic Birds: Above the Heads of Dinosaurs. University of California Press, Berkeley. 